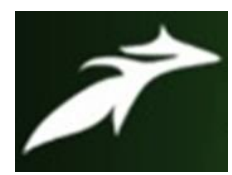

Rayavarapu Jessy Samyuktha et al, Int. Journal of Advances in Agricultural Science \& Technology,

Vol.8 Issue.10, October-2021, pg. 116-121

ISSN: 2348-1358

Impact Factor: 6.057

NAAS Rating: 3.77

\title{
Utilization of Soil Health Card in Achieving Surplus Food Production in Krishna District of Andhra Pradesh
}

\author{
Rayavarapu Jessy Samyuktha* \\ M.Sc. Ag. (Agricultural Extension \& Communication), Department of Agricultural Extension \& Communication, SHAUTS, \\ Prayagraj, Uttar Pradesh \\ Dr. Syed H. Mazhar** \\ Associate Professor, Department of Agricultural Extension \& Communication, SHAUTS, Prayagraj, Uttar Pradesh \\ Dr. (Ms.) Jahanara*** \\ Professor \& Head, Department of Agricultural Extension \& Communication, SHAUTS, Prayagraj, Uttar Pradesh \\ DOI: 10.47856/ijaast.2021.v08i10.013
}

\begin{abstract}
Soil serves as a combination of minerals, organic matter, air, water and the countless micro-organisms that together support life on earth. Continued degradation of soils has adversely affected crop productivity in the country. The soil health has been impaired due to emergence of multi nutrient deficiencies and falling carbon levels. Government of India planned to issue Soil Health Cards to all the farmers under the scheme Soil Health card Scheme and launched this scheme in 2015. Soil Health Card Scheme has helped India achieve surplus capacity in food grain production. The study was based on both primary and secondary data. The study was conducted in few selected villages of Krishna district of Andhra Pradesh in which it was found that Soil Health Card scheme is being implemented and the farmers were aware of SHCS and are being motivated to utilize the information given in soil health cards. Andhra Pradesh has issued most number of soil health cards to its farmers. It is concluded that majority of respondents have medium level of knowledge and utilization of SHC. Nearly $50 \%$ of respondents were utilizing the information given by $\mathrm{SHC}$ and stated that there is increase in production.
\end{abstract}

Keywords: Soil Health Card Scheme, Soil health card, Utilization, Surplus food grain production etc.

\section{INTRODUCTION}

Soil is a natural dynamic body on the surface of earth which composed of organic matter, minerals, gases, liquids and micro-organism. It has basic functions, it provides medium for plant growth, water storage, supply and purification, work as a modifier of Earth's atmosphere, provide habitat for organisms, work as a shield for water loss problems. Soils are the resources that support and sustain a huge diversity of life forms on earth with its diverse physical, chemical and biological properties. The health of those dynamic resources is a measure of a complex set of physical, chemical and biological interactions that support healthy plant growth. Unhealthy soils that do not contain enough nutrients to support crop growth need more input, use input inefficiently, give less productivity per unit of input and its productivity potential gets weakened with time.

A soil with poor health leads to severe food and nutrient security problems like hunger and malnutrition in the world. Unfortunately, the majority of the world's soil resources are in only fair, poor or very poor condition. Also, 25 to 40 billion tonnes of top soil are lost through 


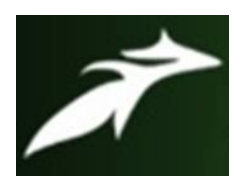

Rayavarapu Jessy Samyuktha et al, Int. Journal of Advances in Agricultural Science \& Technology, Vol.8 Issue.10, October-2021, pg. 116-121

ISSN: 2348-1358

Impact Factor: 6.057

NAAS Rating: 3.77

erosion every year that significantly reduces the soil's ability to store and cycle water and nutrients. Industrialization of agriculture, deforestation, and fast rate of urbanization are considered as some of the prime reasons behind accelerated losses of soil health.

Soil health plays a vital role to ensure sustainable agricultural production. Soil health needs to be assessed at regular intervals so as to ensure that farmers apply the required nutrients while taking advantage of the nutrients already present in the soil. Farmers will be able to know how much nutrients are already available in the soil and how much will have to be provided additionally for a particular crop through soil testing. To popularizing soil testbased fertilizer usages, soil health card is a tool to help the farmer to monitor and improve soil health based on recommendations and enables the farmer to use the soil and crop specific fertilizers. It provides a qualitative assessment of soil health and reclamation measures to the problematic soil. Padmaja B. (2018)

\section{SOIL HEALTH CARD SCHEME}

The Government of India is launched Soil Health Card Scheme on 19 February in 2015 at Suratgarh Rajasthan. Gujrat was the first state to introduce the soil health card scheme in 2003-04 to initiate scientific measures for soil health. The scheme has been introduced to assist State Governments to issue SHCs to all farmers in the country. SHC provides information to farmers on nutrient status of their soil along with recommendation on appropriate dosage of nutrients to be applied for improving soil health and its fertility.

A soil health card is a printed card given to the farmer that contains the status of various plant nutrients available in the soil as well as the dosage of different fertilizers for the major crops grown in the farmland based on the soil tests.

\section{PERFORMANCE OF SOIL HEALTH CARD SCHEME \\ Soil Health Card Scheme has helped India achieve surplus capacity in food grain production.}

As per the data of July 2015, Government of India has covered 34 lakh farmers under the scheme. Andhra Pradesh has issued most number of soil health cards to its farmers. Punjab and Tamil Nadu are way forward in collecting the soil samples. More than 11 crore SHCs have been issued in two phases since the scheme was launched five years ago. They are providing funds to the states to issue soil cards to their respective farmers. When the scheme was launched a sum of Rs.27 crore was set aside for the scheme. Chowdhary (2018).

\section{RESEARCH METHODOLOGY}

The present study was conducted in Penamaluru and Gudivada mandals of Krishna district of Andhra Pradesh. A total of 120 respondents were selected (24 soil health card holders from each selected village) randomly. The study was based on primary and secondary data. Descriptive research design was used for the present study on Utilization of Soil Health Cards in Achieving Surplus Food Production. Descriptive research design is used to describe the characteristics of a population or phenomenon being studied. The data was collected from 


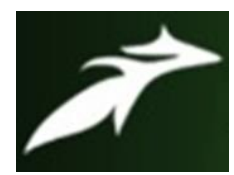

Rayavarapu Jessy Samyuktha et al, Int. Journal of Advances in Agricultural Science \& Technology, Vol.8 Issue.10, October-2021, pg. 116-121

ISSN: 2348-1358

Impact Factor: 6.057

NAAS Rating: $\mathbf{3 . 7 7}$

respondents by using the pre structured interview schedule. Data analysis is done through frequency and percentage distribution using statistical tools.

\section{RESULTS AND DISCUSSION}

Table-1. Distribution of respondents according to their Utilization of Soil Health Cards in achieving surplus food production.

\begin{tabular}{|c|c|c|c|c|}
\hline \multirow[t]{2}{*}{ S.No } & \multirow[t]{2}{*}{ Statement } & \multicolumn{3}{|c|}{ Using information given by $\mathrm{SHC}$} \\
\hline & & Completely & Some extent & Never \\
\hline \multicolumn{5}{|c|}{ Macro nutrients } \\
\hline 1. & $\begin{array}{l}\text { Application of organic carbon in the soil } \\
\text { as per information given in SHC. }\end{array}$ & $84(70.00)$ & $12(10.00)$ & $24(20.00)$ \\
\hline 2. & $\begin{array}{l}\text { Application of NPK in the soil as per } \\
\text { information given in SHC }\end{array}$ & $89(74.17)$ & $10(8.33)$ & $21(17.50)$ \\
\hline 3. & $\begin{array}{l}\text { Application of other macro nutrients ( } \mathrm{S} \text {, } \\
\mathrm{Ca}, \mathrm{Mg} \text { ) in the soil as per information } \\
\text { given in SHC. }\end{array}$ & $91(75.83)$ & $9(7.50)$ & $20(16.67)$ \\
\hline \multicolumn{5}{|c|}{ Micro nutrients } \\
\hline 1. & $\begin{array}{l}\text { Application of Zinc in the soil as per } \\
\text { information given in SHC. }\end{array}$ & $63(52.50)$ & $39(32.50)$ & $18(15.00)$ \\
\hline 2. & $\begin{array}{l}\text { Application of Copper in the soil as per } \\
\text { information given in SHC. }\end{array}$ & $56(46.67)$ & $31(21.83)$ & $33(27.50)$ \\
\hline 3. & $\begin{array}{l}\text { Application of Boron in the soil as per } \\
\text { the information given in SHC. }\end{array}$ & $59(49.17)$ & $49(40.83)$ & $12(10.00)$ \\
\hline 4. & $\begin{array}{l}\text { Application of Iron in the soil as per the } \\
\text { information given in SHC. }\end{array}$ & $53(44.17)$ & $52(43.33)$ & $15(12.50)$ \\
\hline 5. & $\begin{array}{l}\text { Application of Manganese in the soil as } \\
\text { per the information given in SHC. }\end{array}$ & $61(50.84)$ & $46(38.33)$ & $13(10.83)$ \\
\hline \multicolumn{5}{|c|}{ Biological elements } \\
\hline 1. & $\begin{array}{l}\text { Application of Azotobacter culture in the } \\
\text { soil as per information given in the SHC. }\end{array}$ & $49(40.83)$ & $29(24.17)$ & $42(35.00)$ \\
\hline 2. & $\begin{array}{l}\text { Application of Phosphate solubilizing } \\
\text { bacterial culture in the soil as per } \\
\text { information given in the SHC. }\end{array}$ & $47(39.17)$ & $36(30.00)$ & $37(30.83)$ \\
\hline 3. & $\begin{array}{l}\text { Application Rhizobium culture as per the } \\
\text { information given in the SHC. }\end{array}$ & $51(42.50)$ & $35(29.17)$ & $34(28.33)$ \\
\hline 4. & $\begin{array}{l}\text { Application of Azospirillum culture in } \\
\text { the soil as per information given in the } \\
\text { SHC. }\end{array}$ & $56(46.67)$ & $31(25.83)$ & $33(27.50)$ \\
\hline
\end{tabular}




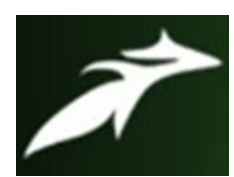

Rayavarapu Jessy Samyuktha et al, Int. Journal of Advances in Agricultural Science \& Technology, Vol.8 Issue.10, October-2021, pg. 116-121

ISSN: 2348-1358

Impact Factor: 6.057

NAAS Rating: 3.77

\begin{tabular}{|l|l|c|c|c|}
\hline \multicolumn{2}{|l|}{ Soil chemical parameters } & $24(20.00)$ & $42(35.00)$ \\
\hline 1. & $\begin{array}{l}\text { Application of lime in the soil as per } \\
\text { information related to soil pH as given in } \\
\text { the SHC. }\end{array}$ & $54(45.00)$ & $25(20.84)$ & $34(28.33)$ \\
\hline 2. & $\begin{array}{l}\text { Application of Gypsum in the soil as per } \\
\text { information given in the SHC. }\end{array}$ & $61(50.83)$ & $29(24.17)$ & $28(23.33)$ \\
\hline 3. & $\begin{array}{l}\text { Use of good quality water and carried } \\
\text { out practices like bunding and green } \\
\text { manuring as per information given in } \\
\text { SHC. }\end{array}$ & $63(52.50)$ & & \\
\hline
\end{tabular}

Table-2. Benefits of Soil Health Cards.

\begin{tabular}{|l|l|c|c|c|}
\hline S.No. & $\begin{array}{l}\text { Benefits you get from Soil health } \\
\text { card }\end{array}$ & Agree & Disagree & Undecided \\
\hline 1. & $\begin{array}{l}\text { After adopting all the } \\
\text { recommendations given by SHC, } \\
\text { crop yield increases. }\end{array}$ & $99(82.50)$ & $10(8.33)$ & $11(9.17)$ \\
\hline 2. & Soil health is maintained. & $101(84.17)$ & $9(7.50)$ & $10(8.33)$ \\
\hline 3. & $\begin{array}{l}\text { Excess usage of chemical fertilizers } \\
\text { is reduced. }\end{array}$ & $82(68.33)$ & $11(9.17)$ & $27(22.50)$ \\
\hline 4. & Increase in production & $71(59.17)$ & $21(17.50)$ & $28(23.33)$ \\
\hline
\end{tabular}

From the above table-2. it is revealed that 82.50 per cent of respondents agreed that their crop yield is increased after adopting all the recommendations given by SHC, 84.17 per cent of respondents agreed that the soil health is maintained, 68.33 per cent of respondents agreed that excess usage of chemical fertilizers is reduced and 59.17 per cent respondents agreed that the production is increased.

Table-3. Overall Distribution of respondents according to their level of Utilization of Soil Health Cards.

\begin{tabular}{|c|l|c|c|}
\hline S.No & \multicolumn{1}{|c|}{ Utilization of Soil Health Cards } & Frequency & Percentage \\
\hline 1 & Low (18-30) & 29 & 24.17 \\
\hline 2 & Medium (31-42) & 59 & 49.16 \\
\hline 3 & High (43-54) $\quad$ Total & 32 & 26.67 \\
\hline \multicolumn{2}{|c|}{} & $\mathbf{1 2 0}$ & $\mathbf{1 0 0 . 0 0}$ \\
\hline
\end{tabular}

The data presented in the above table-3. reveals that majority of respondents belonged to the medium level of utilization of Soil health cards. This group alone constitutes 49.16 per cent of the total sample. A considerable number of respondents 24.17 per cent were from low level of utilization and 26.67 per cent respondents were found to be high level of utilization of Soil health cards. 


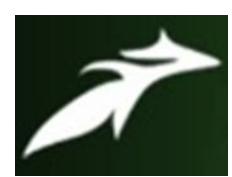

Rayavarapu Jessy Samyuktha et al, Int. Journal of Advances in Agricultural Science \& Technology, Vol.8 Issue.10, October-2021, pg. 116-121

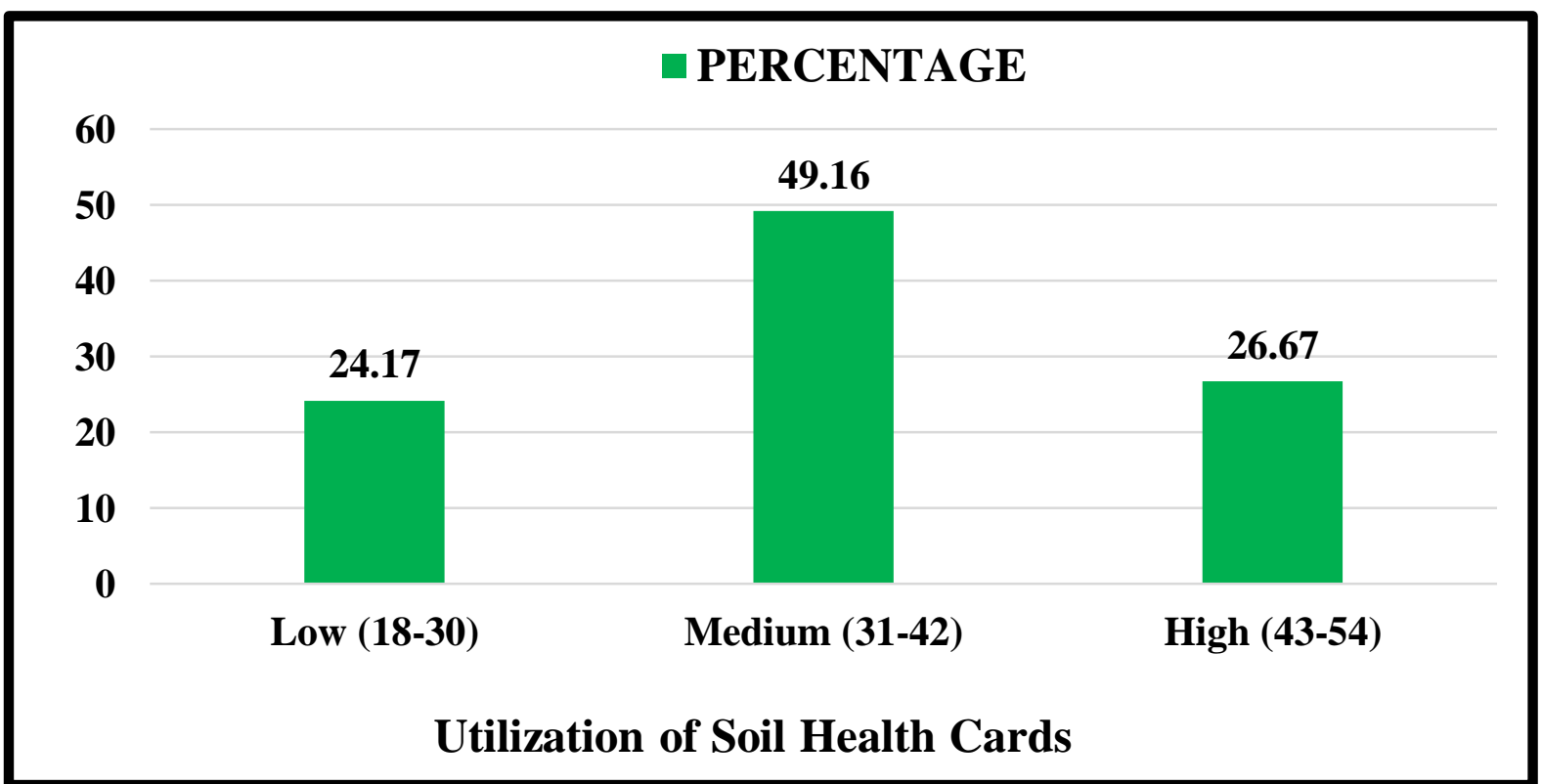

Fig. 1. Overall distribution of respondents according to their level of utilization of soil health cards.

\section{CONCLUSION}

It is concluded that majority of respondents belonged to the medium level of utilization of Soil health cards. This group alone constitutes 49.16 per cent of the total sample. A considerable number of respondents 24.17 per cent were from low level of utilization and 26.67 per cent respondents were found to be high level of utilization of Soil health cards and 82.50 per cent of respondents agreed that their crop yield is increased after adopting all the recommendations given by SHC, 84.17 per cent of respondents agreed that the soil health is maintained, 68.33 per cent of respondents agreed that excess usage of chemical fertilizers is reduced and 59.17 per cent respondents agreed that the production is increased.

\section{REFERENCES}

[1]. Bhayal, V., Wankhede, A., Chowdary, S. and Jain, S.K. (2019). Impact and Awareness of Soil Health Card with reference to maize production in Dhar district of Madhya Pradesh, International journal of Applied Agricultural Research, 14(2): 79-85.

[2]. Chouhan, R.S., Sharma, H.O., Rathi, D. and Niranjan, H.K. (2017). Impact of Soil Health Card Scheme on Farmers' Income -A Case Study of Kharif Crops in Madhya Pradesh.

[3]. Chowdary, K.R., Jayalakshmi, M. and Prasadbabu, G. (2018).Factors Determining the Soil Health Card Adoption Behaviour among Farmers in Andhra Pradesh,Asian J. Soil Sc. 13(1): 76-79. 


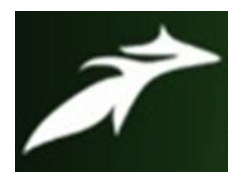

Rayavarapu Jessy Samyuktha et al, Int. Journal of Advances in Agricultural Science \& Technology, Vol.8 Issue.10, October-2021, pg. 116-121

ISSN: 2348-1358

Impact Factor: 6.057

NAAS Rating: 3.77

[4]. Makadia, J.J., Mistry, H.H. and Kuthe, S.B. (2017). Impact of Soil Health Card on Fertilizer Consumption and Yield of Sugarcane and Kharif Paddy in Gujarat State. Economic Affairs. 60(4): 61-66.

[5]. Padmaja.B., and Angadi, J.G. (2018). Utilization of Soil Health Card by farmers in Nutrient Management., Int.j.Curr.Microbiol.App.Sci. 7(12): 1583-1592.

[6]. Parewa, H.P., Jain, L.K., Mahajan, G.R. and Bhimawat, B.S. (2016). Soil Health Card: A Boon for the Indian Farmers. Ind. J. Plant Soil. 3(2):77-81.

[7]. Patel, G.G., Lakum, Y.C., Mishra, A. and Bhatt, J.H. (2017). Awareness and Knowledge Regarding Soil Testing and Utility Perception of Soil Health Card. Int. J. Curr. Microbiol. Appl. Sc. 6(10): 329-334.

[8]. Purakayastha, T.J., Pathak, H., Kumari, Savita., Biswas, Sunanda and Singh, Anjali. (2019). Soil Health Card Development for Efficient Soil Management in Haryana, Ind. Soil Till. Res. 19(1): 294-305.

[9]. Singh, J.M., Kumar, Sanjay and Grover, D.K. (2019). Impact of Soil Health Card Scheme on Production, Productivity and Soil Health in Punjab. Agrl. Sit. Ind. 76(8): 26-30. 